\title{
The Efficiency of Different Methods of Lime Application During Soil Preparation
}

\author{
D. SAAYMAN and L. VAN HUYSSTEEN \\ Oenological and Viticultural Research Institute, Private Bag X5026, Stellenbosch, 7600 \\ The authors wish to express their thanks and appreciation to:
}

1. Mr. A. Carstens (Fruit and Fruit Technology Research Institute) for his invaluable contribution in taking the photographs under highly adverse conditions.

2. Stellenbosch Farmer's Winery, and in particular Messrs. G. H. Raubenheimer \& W. W. Swanepoel, for financial and technical assistance and the use of the implements.

3. Misses A. E. Theron, A. Verster, D. M. Dwyer and W. E. Jackson of the Soil Science Section of the Oenological and Viticultural Research Institute for their technical assistance in the field and laboratory.

\begin{abstract}
The efficiency of a newly developed lime applicator, mounted on different soil preparation implements and in combination with different methods of lime application, was studied. The distribution and placement of lime were tracked by using fluorescent pigments mixed with the lime, and subsequent photography under UV light. It was found that lime, applied on the surface before the deep-ploughing operation, gave surprisingly good results in comparison to blown-in lime, or conventional methods, but that the lime applicator in combination with a winged plough, needs modification. Double ploughing the soil seems to be an efficient method of ensuring proper mixing of lime and soil.
\end{abstract}

It is well-known that most of the soils of the Western Cape are acid, especially the subsoil. Analyses of soil samples during the last three years by the OVRI and the Extension Service indicated that $78 \%$ of the samples from the Western Cape had a $\mathrm{pH}(\mathrm{KCl})$ of lower than 5,5. It has already been established that aluminium becomes toxic at a low soil $\mathrm{pH}$, and that for most plants the exchangeable aluminium should be kept below 0,2 me\% (Reeve \& Sumner, 1970a; Kotzé \& Deist, 1972; Kotzé, 1973). Excess aluminium can be eliminated by liming with various liming materials. However, because there is no consistent relationship between exchangeable aluminium and soil $\mathrm{pH}$ (the most commonly measured soil property), the latter parameter cannot be used to estimate the lime requirement of a soil. It is, therefore, necessary to use special analytical procedures to determine the lime requirement of a soil (Shoemaker, McLean \& Pratt, 1961; Eksteen, 1969; Reeve \& Sumner, 1970b). The standard practice at the OVRI is to do a lime requirement determination, and calculate $\mathrm{R}$-values (exchangeable $\mathrm{Ca}^{++}+\mathrm{Mg}^{++} /$exchangeable $\mathrm{H}^{+}$), as described by Eksteen (1969), on all soil samples having a $\mathrm{pH}(1 \mathrm{M} \mathrm{KCl})$ of lower than 5,0. An $\mathrm{R}$-value of 5,0 is used for wine grapes, and it has been found in practice that this value ensures that a soil is limed to approximately $\mathrm{pH}$ 5. At this $\mathrm{pH}$, according to Kotzé (1973), aluminium is reduced to non-toxic levels.

At present, various liming materials are commercially available, viz. calcitic lime (agricultural lime), dolomitic lime, slaked lime (calcium hydroxide), and calcium silicate. Their efficiency and properties were investigated by Kotzé (1978). It should be borne in mind, too, that the efficiency of lime depends on the fineness to which it has been ground. It is known that liming materials currently available vary considerably in this respect (G. J. Loubser* \& G. H. Raubenheimer $\dagger$, 1979-personal communication).

Calculations concerning lime requirements are based on the assumption that a $100 \%$ mixing of liming material and soil is achieved. In practice, the most pressing problems are that it is mainly the subsoil that requires liming, and that it is extremely difficult to achieve a thorough mixing of liming material and subsoil. Although it was suspected that the conventional methods of broadcasting lime before deep ploughing, and/or casting it against the slanted wall of the ploughed furrow were not very efficient, little was done, until recently, to improve these methods. However, in response to a recent visit of a German tillage expert (Schulte-Karring, 1977) a wine firm in Stellenbosch developed an implement that could apply lime to the subsoil during deep ploughing. In order to evaluate the effectiveness of the application and distribution of liming materials by means of this implement, a series of investigations were conducted at Nietvoorbij towards the end of 1978 .

\section{MATERIALS AND METHODS}

Implements: A crawler tractor (Caterpillar D8) was used in conjunction with two types of deep ploughing implements mounted on hydraulic linkages, viz.: i) a Delve plough in combination with a ripper shank (Fig. 1), and ii) a Winged plough (Fig. 2). For applying the lime, a Solfméc $\ddagger$ type sulphur duster, equipped with a tempered stainless steel fan, driven by a hydraulic motor, was mounted on the implements (Fig. 3). The lime dropped directly on the fan, was distributed by a $63 \mathrm{~mm}$ steel pipe, and released in the bottom of the furrow just behind the share in the case of the delve plough. In the case of the winged plough, the lime was released on a horizontally mounted plate underneath the wing shares, in order to facilitate lateral distribution of the lime. Under the conditions of this investigation the apparatus could deliver approximately seven tons of calcitic lime per hectare.

${ }^{*}$ Research chemist, S.F.W.

†Consulting engineer, S.F.W.

$\ddagger$ Van Leer S.A. (Pty) Ltd., Cape Town. 


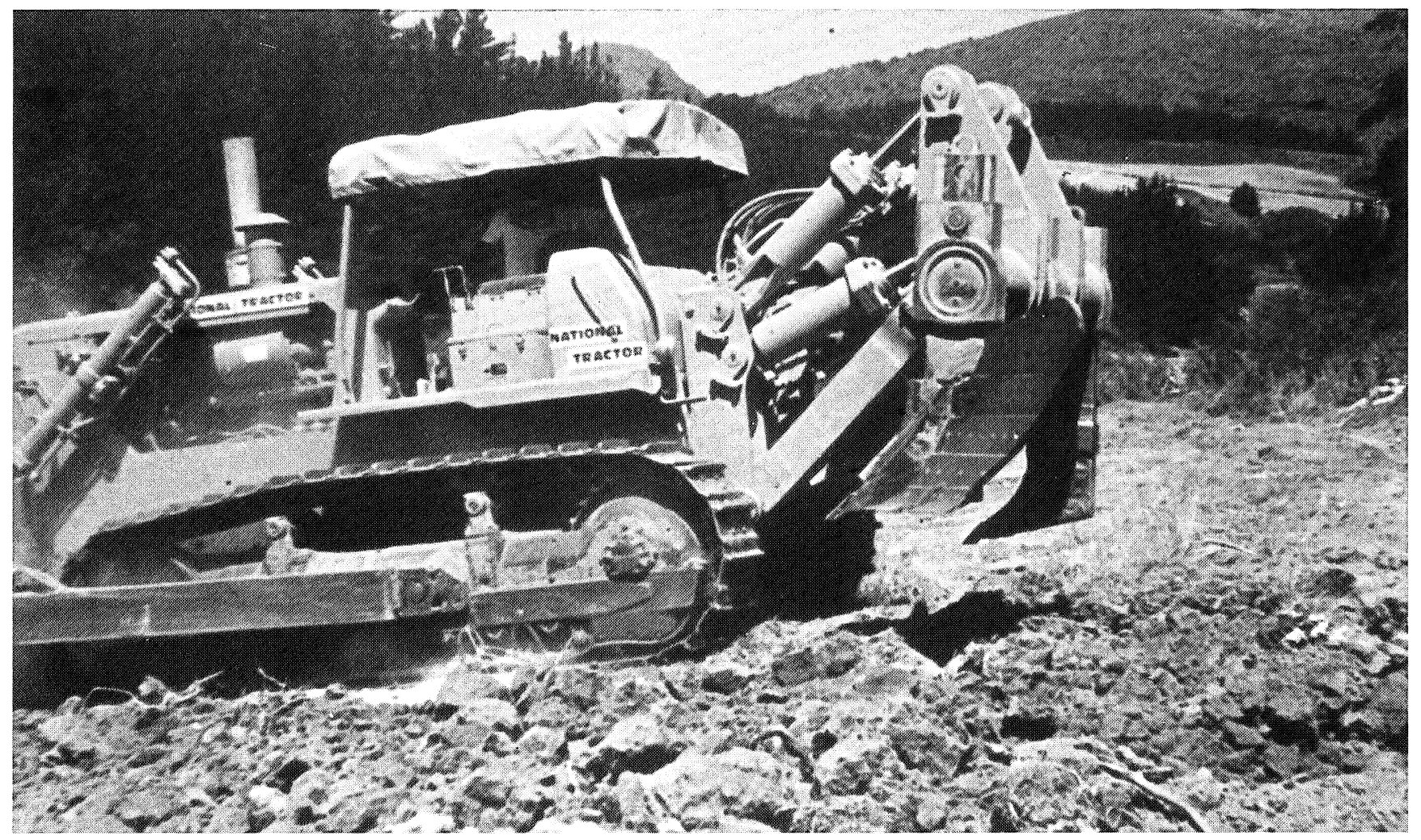

FIG. 1

FIG. 1

Delve plough in combination with ripper shank.

FIG. 2

Winged plough.

FIG. 3

Modified sulphur duster mounted on winged plough to force lime into the subsoil.

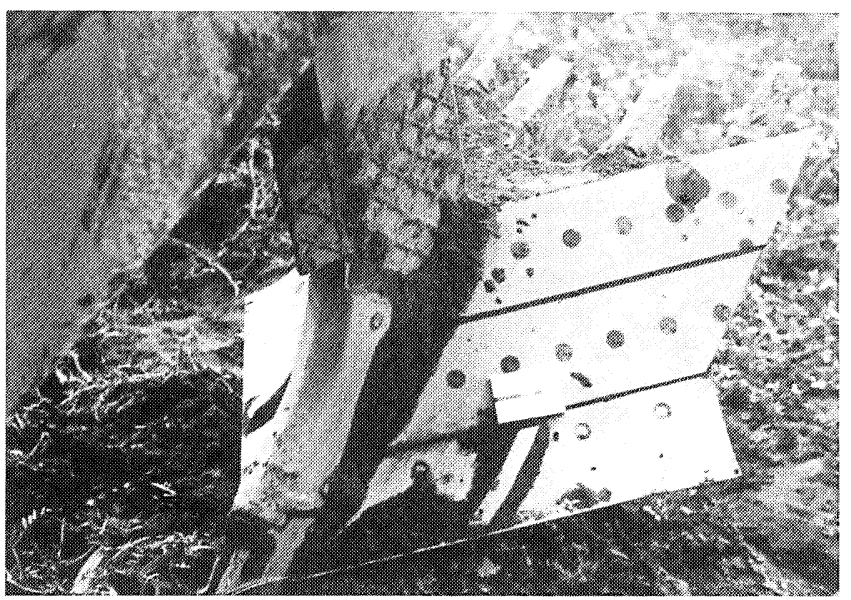

FIG. 2

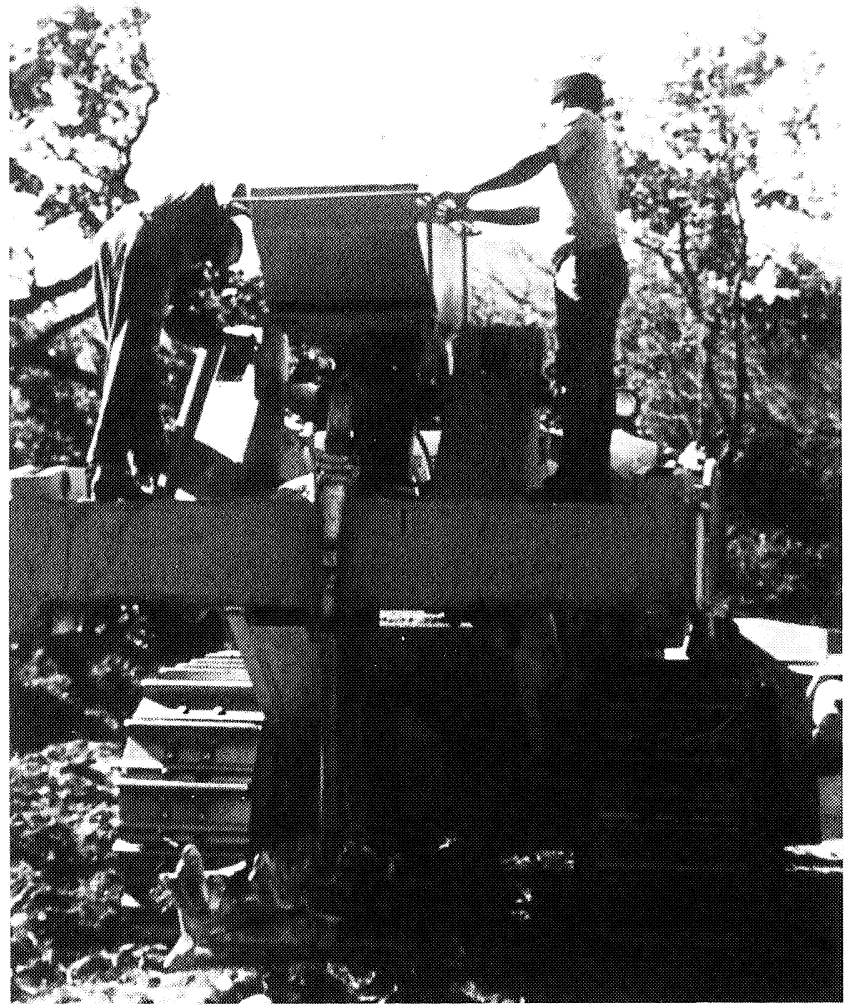

FIG. 3 
Soil and experimental lay-out: The experimental site used was situated on the OVRI experimental farm, Nietvoorbij, and the soil was classified as an Avalon form; Avalon series (MacVicar \& Soil Survey Staff, 1977), having a pH of 6,2 and 4,8 in the top- and subsoil respectively, and a lime requirement of 10,3 tons calcitic lime per hectare for a depth of $100 \mathrm{~cm}$. Treatments were applied as shown in Table 1. The lime applied on the surface was broadcast by hand prior to soil preparation. Plot dimensions were $50 \mathrm{~m} \times 3,5 \mathrm{~m}$.

Each of the plots was ploughed and subsequently divided into two sub-plots, and one half of each treatment plot ploughed to a depth of $30 \mathrm{~cm}$ for the second time. Thereafter, all the plots were disced at a depth of $15 \mathrm{~cm}$ in order to mix the surface applied lime thoroughly with the topsoil.

TABLE 1

Implements and mode of lime application used for the different treatments in the experiment

\begin{tabular}{c|c|c|c|c}
\hline \multirow{2}{*}{ Implement } & & \multicolumn{2}{|c}{$\begin{array}{c}\text { Mode of lime application } \\
\text { (\% of total requirement) }\end{array}$} \\
\cline { 3 - 5 } & $\begin{array}{c}\text { Treat- } \\
\text { ment* } \\
\text { No. }\end{array}$ & $\begin{array}{c}\text { On } \\
\text { Surface }\end{array}$ & Blown-in & $\begin{array}{c}\text { Against } \\
\text { slanted } \\
\text { wall of } \\
\text { furrow }\end{array}$ \\
\cline { 3 - 5 } & D1 & 50 & - & 50 \\
\hline $\begin{array}{c}\text { Delve plough } \\
\text { (Share \& ripper) }\end{array}$ & D2 & 100 & - & - \\
\hline Winged plough & W3 & 33 & 67 & - \\
& W2 & 33 & 100 & - \\
\hline
\end{tabular}

*Each treatment was subsequently split into two subplots, of which one was deep ploughed to a depth of $300 \mathrm{~mm}$.

Material applied: The calcitic lime, obtained from Bredasdorp, had a composition as shown in Table 2. It was thoroughly mixed beforehand in a ratio of nine to one with a 2:1 Orange MS and Orange LS Flare Fluorescent Pigments mixture. Preliminary tests showed that a $10 \%$ concentration (mass basis) of fluorescent pigments in the lime was sufficient to be observed under UV light, even when this fluorescent lime was thoroughly mixed with the soil. The lime/pigment mixture was applied in accordance with the lime requirement of the specific soil, i.e. 10,3 tons of calcitic lime per hectare.

Determination of the distribution of lime: Two profile pits were dug on each plot, including those which were double ploughed. The distribution of the fluorescent material was subsequently photographed at night using Agfa CT18, 50ASA film as well as Kodak 3X, 100ASA black and white film, the lighting being supplied by two $1,2 \mathrm{~m}$ length ultraviolet tubes $(220 \mathrm{~V}, 40 \mathrm{~W})$. The profile wall photographed was diagonally across the direction of ploughing. In addition to using photography, the distribution of fluorescent lime was plotted by projecting the colour slide image of the profile wall on graph paper in such a manner that the same scale was obtained each time, so that the surfaces affected by lime could be traced. The traced surfaces were subsequently cut out with a pair of scissors, and the total surface measured with an electronic area meter. Soil samples for chemical analyses were taken from the topsoil, as well as from the zones affected by the implement.

\section{RESULTS AND DISCUSSION}

Fig. 4 shows the distribution of topsoil after ploughing with a delve plough, as obtained from black and white photographs. It is clear that the specific delve plough tends to displace the soil sideways, thus creating a tongued pattern of top- and subsoil. It would appear, therefore, that if the topsoil, $25-30 \mathrm{~cm}$ deep, could be correctly limed beforehand by means of conventional farm implements, it would greatly contribute towards obtaining a larger subsoil volume limed to the desired $\mathrm{pH}$ when this soil is subsequently delve ploughed.

Fig. 5 shows the effect obtained by means of the winged plough. Although the total working depth of this implement corresponded with that of the delve plough $(80 \mathrm{~cm})$, less mixing of top and subsoil was obtained. This was to be expected, as this plough was specifically designed for soils having a subsoil with very unfavourable physical and sometimes chemical properties, the aim being to loosen the soil thoroughly without bringing the inferior subsoil to the surface. Liming the topsoil and ploughing it afterwards with the winged plough, would therefore create a limed zone of only ca. $45 \mathrm{~cm}$ deep (Fig. 5 ), in comparison with limed zones (tongues) up to a depth of ca. $80 \mathrm{~cm}$ in the case of the delve plough.

The effectiveness of the different modes of lime application is shown in Figs 6a-6e, while Figs 7 and 8 show the actual photographic images obtained with treatments D1 and W1. Conventional lime application, in combination with the delve plough (D1 in Table 1), shows a distribution pattern corresponding with the typical mixing pattern of the delve plough (Fig. 4). A general, tongued liming depth of ca. $55 \mathrm{~cm}$ was obtained (Fig. 6a). This restricted depth was due to the fact that the furrow was partially filled with loose earth that tumbled back into the furrow immediately behind the share, thus making it impossible to place the lime on the bottom of the furrow.

Liming the surface only before delve ploughing (treatment D2), resulted in a surprisingly effective distribution of lime throughout the profile (Fig. 6b). Again tongued liming patterns were observed, in this instance up to a depth of $48 \mathrm{~cm}$.

TABLE 2

Composition of calcitic lime used in study*

\begin{tabular}{|c|c|c|c|c|c|c|c|c|c|}
\hline \multirow{2}{*}{$\begin{array}{l}\text { Moisture content } \\
(\%)\end{array}$} & \multirow{2}{*}{$\begin{array}{c}\mathrm{CaCO}_{3}+\mathrm{MgCO}_{3} \dagger \\
(\%)\end{array}$} & \multicolumn{8}{|c|}{ Particle size distribution (mesh) $-(\%)$} \\
\hline & & $<10$ & $10-20$ & $20-40$ & $40-80$ & $80-100$ & $100-200$ & $200-235$ & $>235$ \\
\hline 4 & 79,54 & 9,4 & 10,7 & 12,9 & 44,6 & 13,4 & 5,5 & 3,0 & 1,5 \\
\hline
\end{tabular}

*Loubser, G. J. \& Raubenheimer, G. H., 1979-unpublished data.

†Soluble in $1 \mathrm{M} \mathrm{HCl}$. 


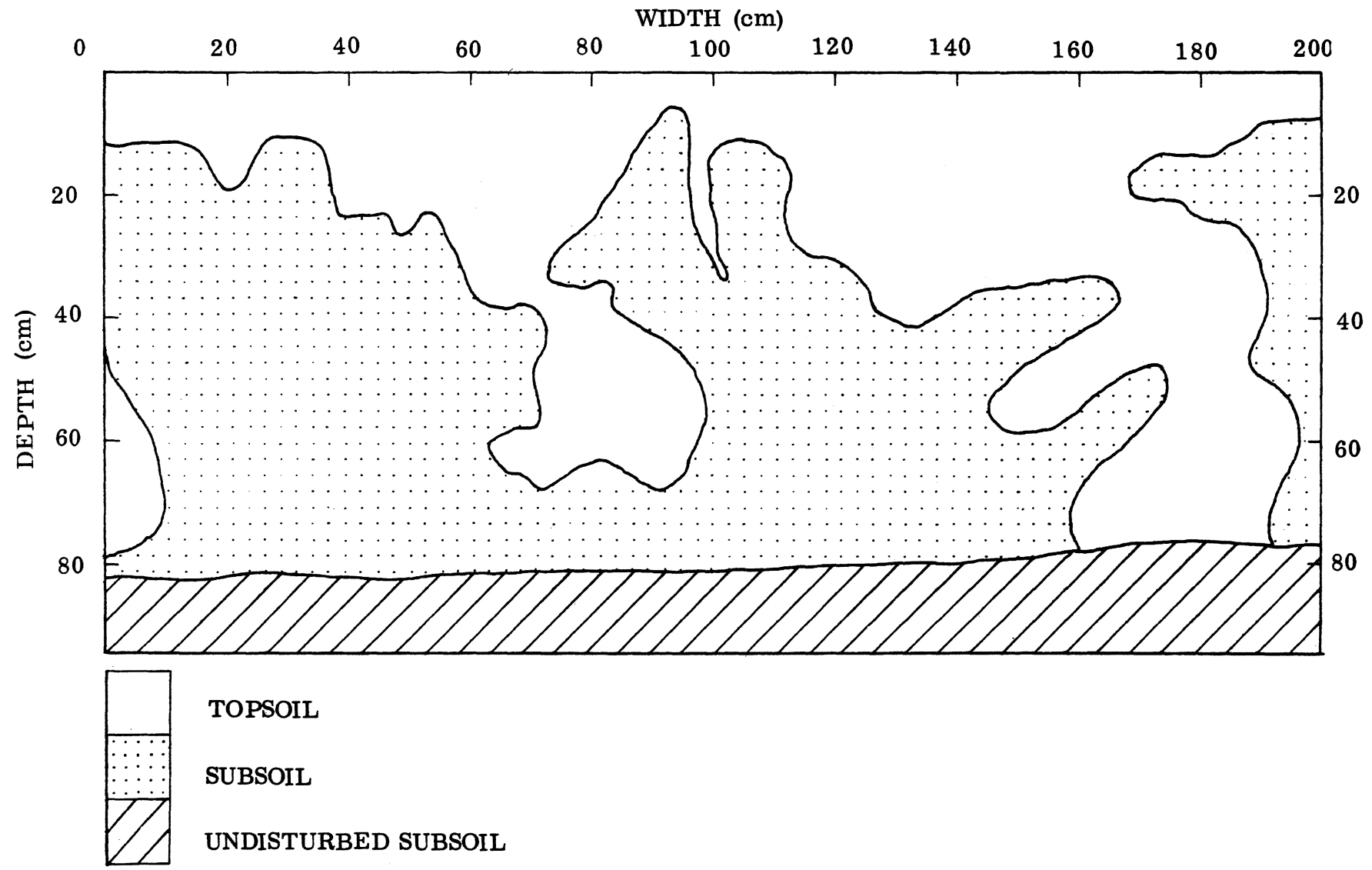

Fig. 4

Cross section of delve-ploughed soil.
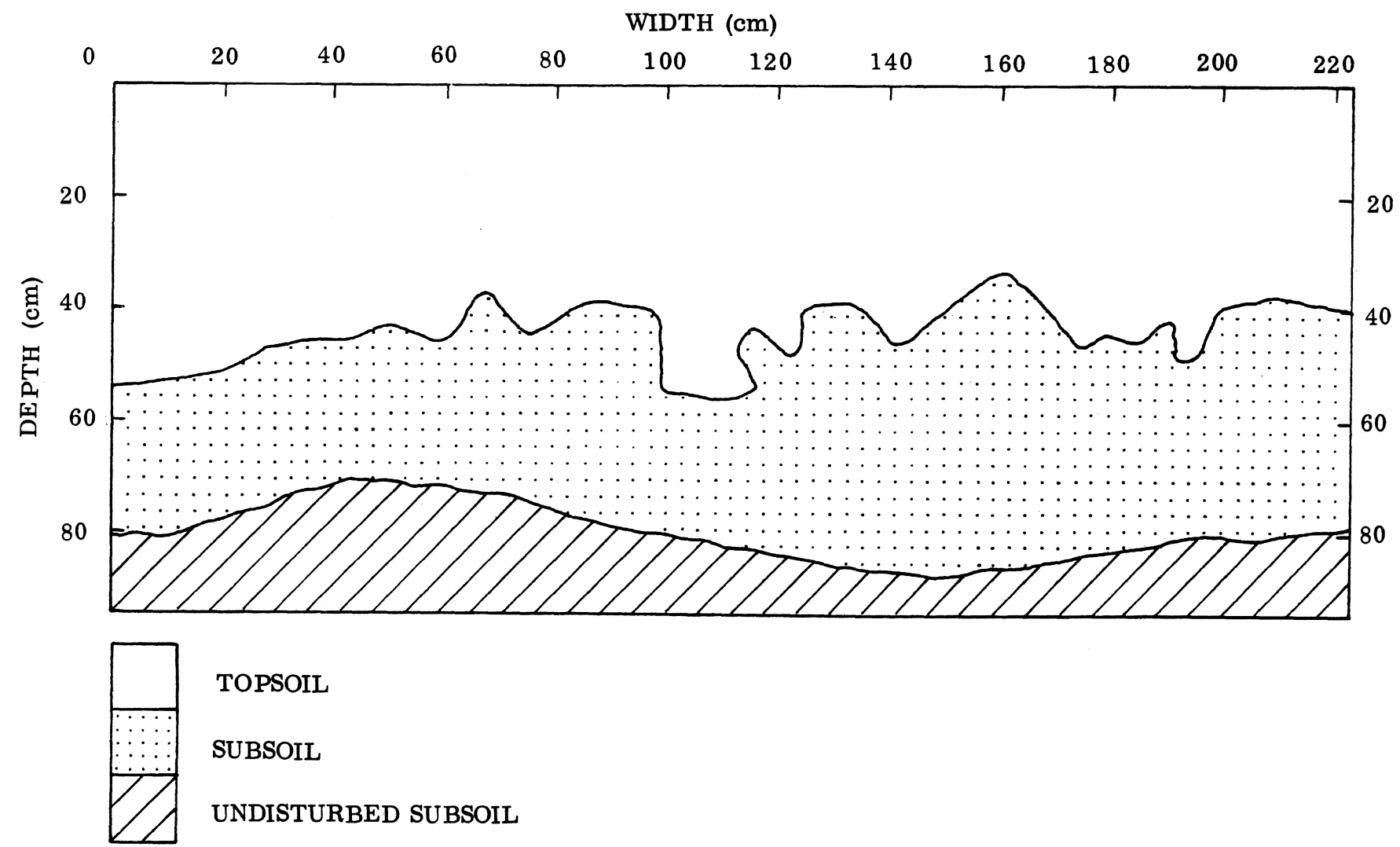

FIG. 5

Cross section of winged-ploughed soil.

S. Afr. J. Enol. Vitic., Vol. 2. No. 1. 1981 

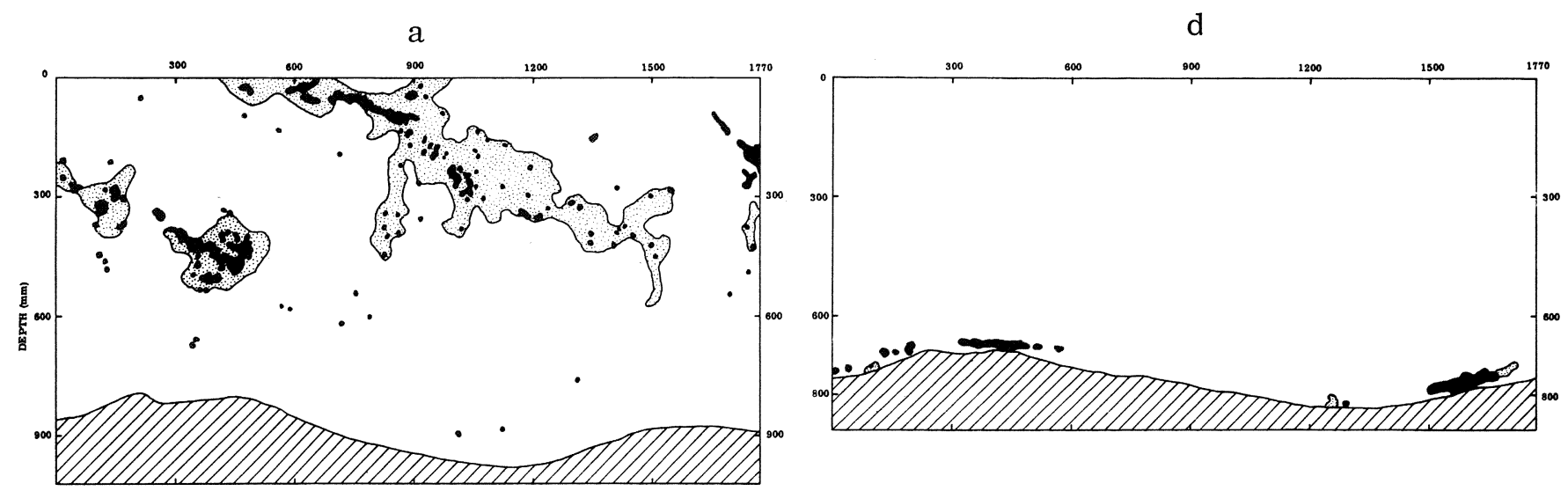

$\mathrm{b}$
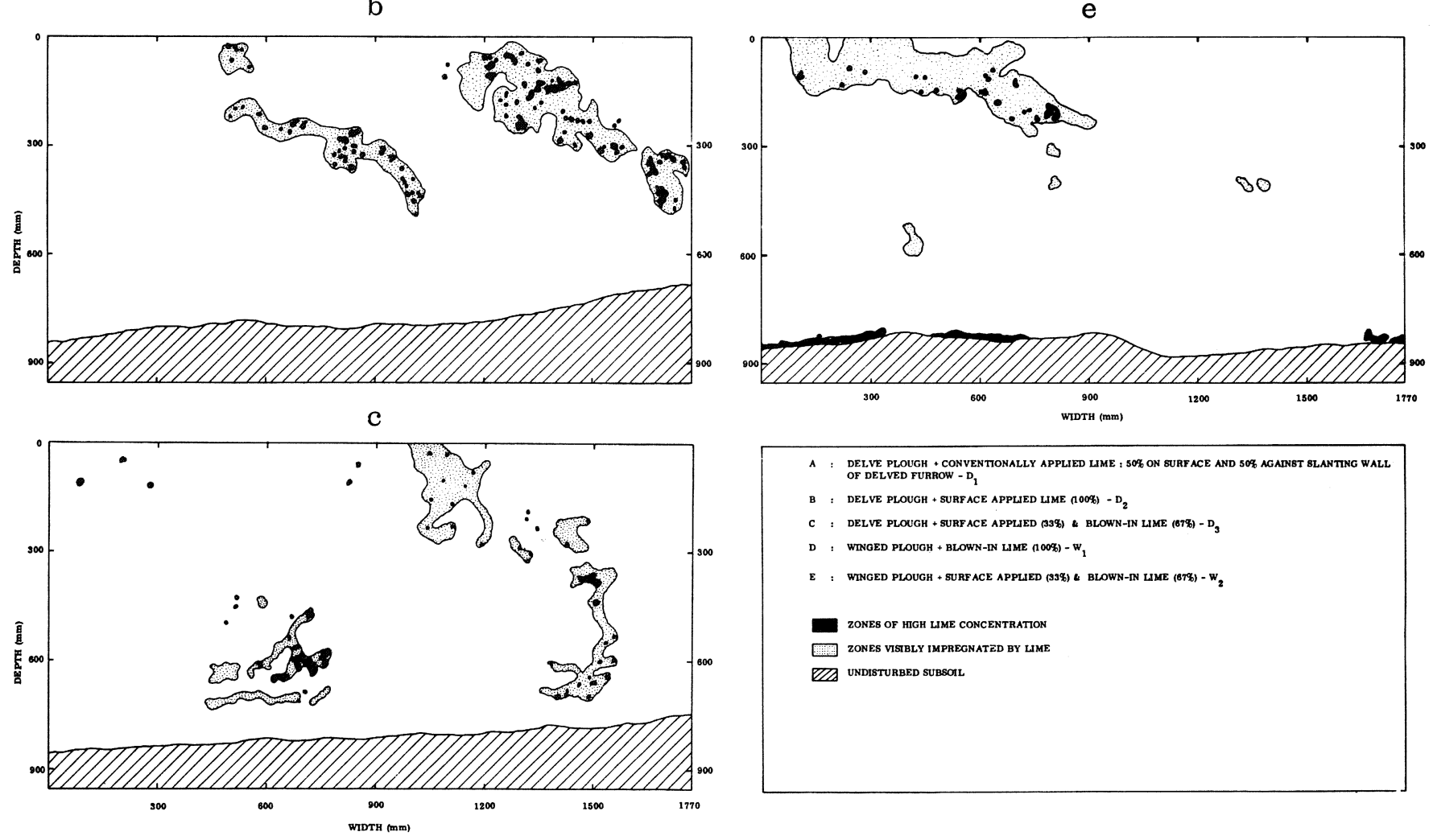

FIG. 6

Lime distribution achieved with different implements and means of applications.

W1

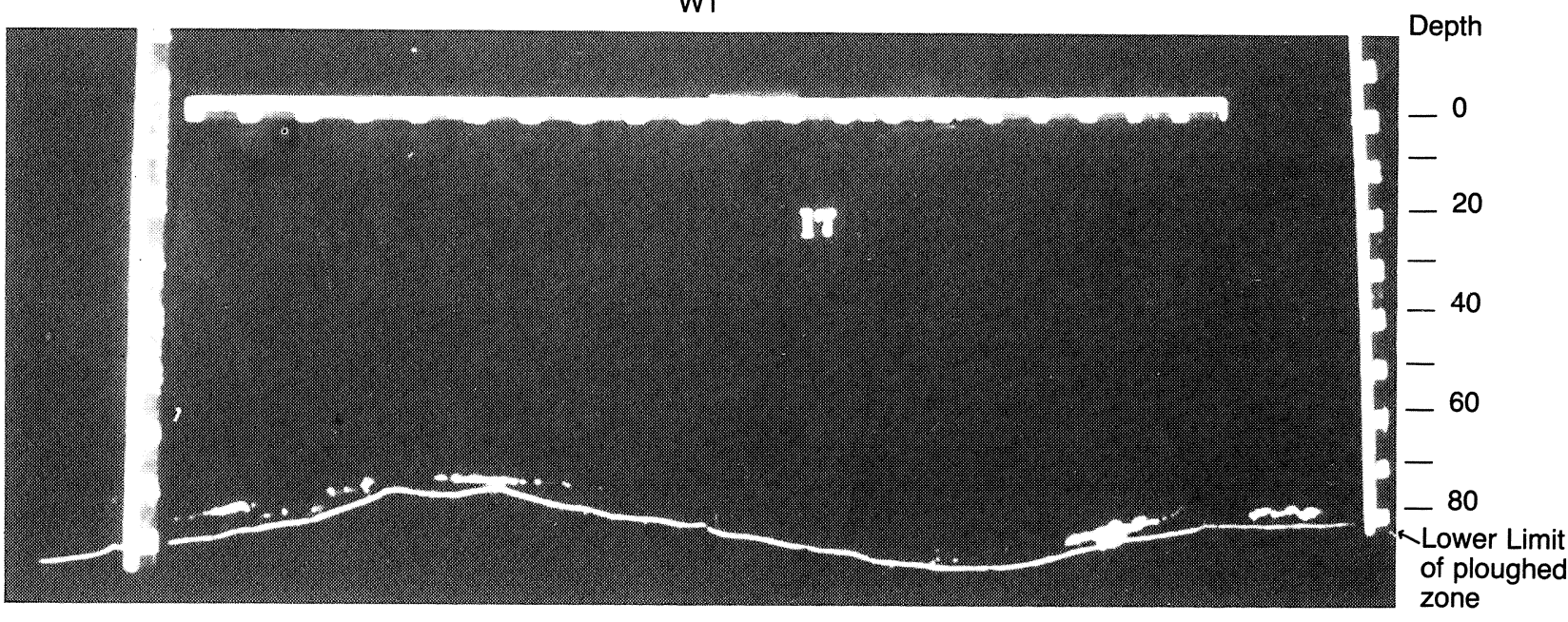

S. Afr. J. Enol. Vitic., Vol. 2. No. 1. 1981 
D1

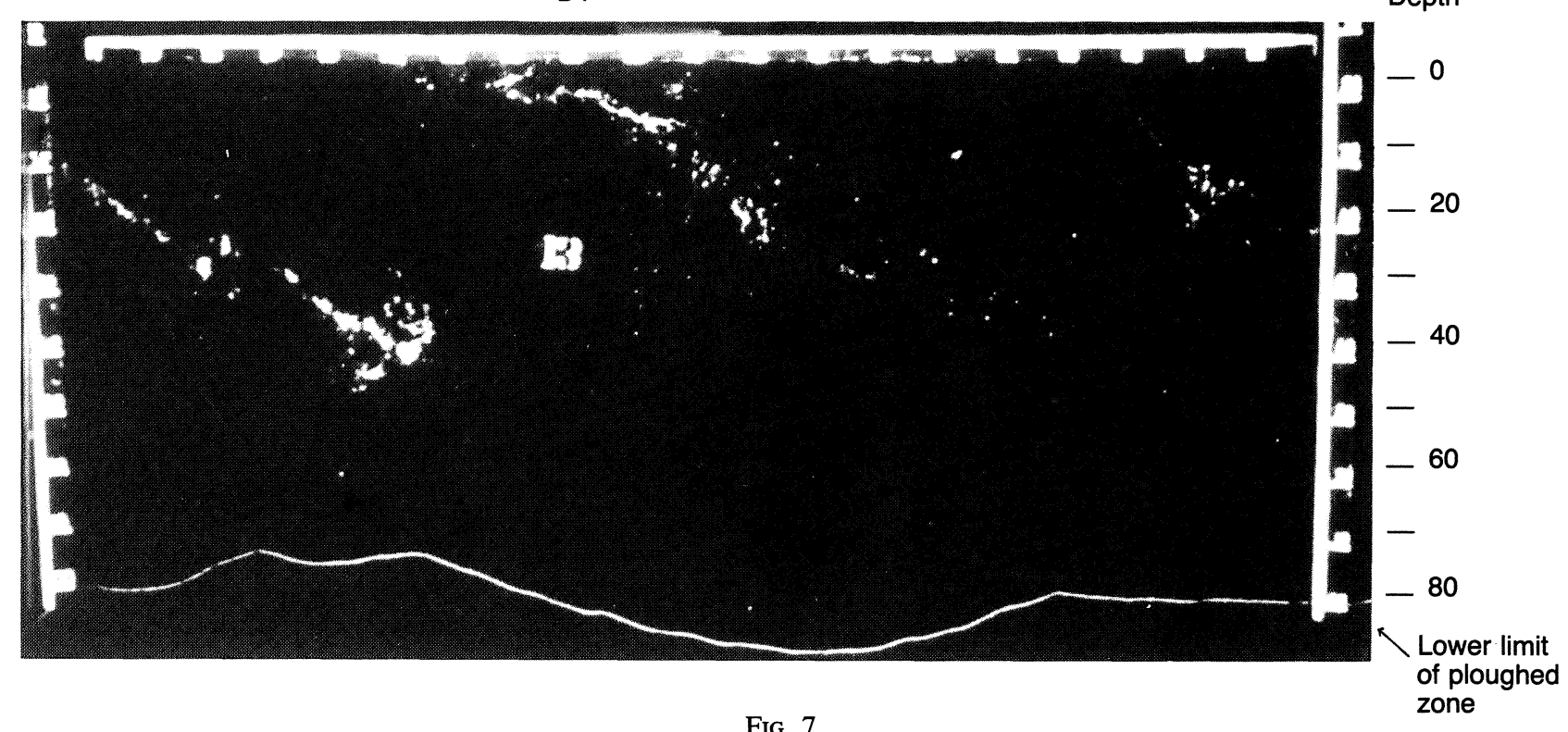

FIG. 7
Treatment D3 (applying 33 per cent of the lime on the surface and placing the rest deeply by means of the blower) also showed a tongued distribution of lime, but in this case, although a liming depth of ca. $72 \mathrm{~cm}$ was reached, the lime was much more concentrated in the lower regions of the tongues (Fig. 6c). The net result was deeper lime penetration but in comparison with treatments D1 and D2, a less effective mixing in the upper 60 $\mathrm{cm}$ of soil.

When all the lime was blown in after the winged plough (W1) a disappointingly limited lime distribution was obtained (Fig. 6d). It is clear that the blown-in lime was deposited in a narrow concentrated band ca. $30 \mathrm{~cm}$ wide on the still undisturbed subsoil. This was due to the lime being released at only one depth in the void created underneath the winged share. Under the conditions of this experiment the force of the blower was clearly insufficient to force the heavy lime into the fissures created by the plough, and the lime simply poured straight down to the bottom of the furrow. Fig. 6e shows that virtually the same result was obtained with this implement in combination with surface applied and blown-in lime (W2). The surface applied lime contributed little to a better lime distribution.

The surface areas of the exposed profile walls affected by the different liming treatments are shown in Table 3. These data confirm the impressions obtained by the photographic images and diagrams, showing that, especially in the case of the winged plough, the lime blown in was disappointingly poorly distributed. The results of the chemical analyses of the soil in its natural state and after deep ploughing, are shown in Table 4. These results also show that, in the case of the delve plough, only the topsoil and the ploughed-in tongues were affected by liming, as shown by the exchangeable calcium content of the soil. The poor distribution by means of the winged plough was again confirmed by the high calcium content of the soil on the bottom of the furrow.

TABLE 3

Surface area of profile wall impregnated with lime due to different ploughing and liming techniques

\begin{tabular}{|c|c|c|}
\hline Treatment* & $\begin{array}{l}\text { Depth of } \\
\text { soil layer } \\
\quad(\mathrm{cm})\end{array}$ & $\begin{array}{l}\text { Surface area } \\
\text { impregnated } \\
\text { with lime }(\%)\end{array}$ \\
\hline $\begin{array}{l}\text { D1-Delve plough } \ldots \ldots \ldots \ldots \ldots \\
\text { (Conventional, i.e. surface lime }+ \\
\text { lime against slanted wall) }\end{array}$ & $\begin{array}{r}0-30 \\
30-60 \\
60-84\end{array}$ & $\begin{array}{r}20,05 \\
17,45 \\
0,25\end{array}$ \\
\hline $\begin{array}{l}\text { D2-Delve plough } \ldots \ldots \ldots \ldots \ldots \ldots \\
\text { (Surface lime) }\end{array}$ & $\begin{array}{r}0-30 \\
30-60 \\
60-84\end{array}$ & $\begin{array}{c}20,44 \\
8,33 \\
0,0\end{array}$ \\
\hline $\begin{array}{l}\text { D3-Delve plough } \ldots \ldots \ldots \ldots \ldots \ldots \\
\text { (Surface and blown-in lime) }\end{array}$ & $\begin{array}{r}0-30 \\
30-60 \\
60-84\end{array}$ & $\begin{array}{l}9,71 \\
5,29 \\
9,56\end{array}$ \\
\hline $\begin{array}{l}\text { W1-Winged plough } \ldots \ldots \ldots \ldots \ldots \\
\text { (Blown-in lime) }\end{array}$ & $\begin{array}{r}0-30 \\
30-60 \\
60-80\end{array}$ & $\begin{array}{l}0 \\
0 \\
6,0\end{array}$ \\
\hline $\begin{array}{l}\text { W2-Winged plough } \ldots \ldots \ldots \ldots \ldots \\
\quad \text { (Surface and blown-in lime) }\end{array}$ & $\begin{array}{r}0-30 \\
30-60 \\
60-80\end{array}$ & $\begin{array}{l}15,31 \\
0 \\
5,11\end{array}$ \\
\hline
\end{tabular}

*See Table 1 for treatments.

Ploughing the soil a second time (Fig. 8) only created a better mixing of the lime in the top $30 \mathrm{~cm}$ of soil. This implies that if the soil could be ploughed deeply for a second time, to a depth of for example $80 \mathrm{~cm}$, the tongued liming pattern of Fig. 4 would be largely eliminated, and a thorough mixing of lime and soil would be obtained. 
TABLE 4

Chemical analyses of soil before and after liming and deep ploughing

\begin{tabular}{|c|c|c|c|c|c|c|}
\hline \multirow{2}{*}{ Treatment* } & \multirow{2}{*}{ Position of sample } & \multirow{2}{*}{$\begin{array}{c}\mathrm{pH} \\
(1 \mathrm{M} \mathrm{KCl})\end{array}$} & \multicolumn{4}{|c|}{ Total exchangeable cations (me\%) } \\
\hline & & & $\mathrm{Ca}$ & $\mathrm{Mg}$ & $\mathrm{K}$ & $\mathrm{Na}$ \\
\hline $\begin{array}{l}\text { Control } \ldots \ldots \ldots \ldots \ldots \ldots \\
\text { (No lime) }\end{array}$ & $\begin{array}{l}\text { Topsoil: A1 } \\
\text { Subsoil: } \text { B21 layer } \\
\text { B22 layer }\end{array}$ & $\begin{array}{l}6,18 \\
4,81 \\
4,81\end{array}$ & $\begin{array}{l}4,12 \\
1,20 \\
0,39\end{array}$ & $\begin{array}{l}0,42 \\
0,97 \\
1,10\end{array}$ & $\begin{array}{l}0,48 \\
0,32 \\
1,00\end{array}$ & $\begin{array}{l}0,09 \\
0,06 \\
0,13\end{array}$ \\
\hline$\ldots \ldots \ldots \ldots \ldots$ & $\begin{array}{l}\text { Topsoil } \\
\text { Ploughed-in topsoil tongue } \\
\text { Subsoil tongue }\end{array}$ & $\begin{array}{l}6,35 \\
6,11 \\
5,02\end{array}$ & $\begin{array}{l}4,60 \\
4,77 \\
1,54\end{array}$ & $\begin{array}{l}0,54 \\
0,56 \\
1,26\end{array}$ & $\begin{array}{l}0,20 \\
0,21 \\
0,29\end{array}$ & $\begin{array}{l}0,10 \\
0,12 \\
0,28\end{array}$ \\
\hline $\mathrm{D} 2 \ldots \ldots \ldots \ldots \ldots \ldots$ & $\begin{array}{l}\text { Topsoil } \\
\text { Ploughed-in topsoil tongue } \\
\text { Subsoil tongue }\end{array}$ & $\begin{array}{l}6,32 \\
6,06 \\
4,91\end{array}$ & $\begin{array}{l}5,65 \\
4,05 \\
1,90\end{array}$ & $\begin{array}{l}0,55 \\
0,52 \\
1,16\end{array}$ & $\begin{array}{l}0,31 \\
0,24 \\
0,24\end{array}$ & $\begin{array}{l}0,30 \\
0,16 \\
0,05\end{array}$ \\
\hline$\ldots \ldots \ldots \ldots$ & $\begin{array}{l}\text { Topsoil } \\
\text { Ploughed-in topsoil tongue } \\
\text { Subsoil tongue }\end{array}$ & $\begin{array}{l}5,67 \\
5,85 \\
4,15\end{array}$ & $\begin{array}{l}3,06 \\
3,68 \\
0,75\end{array}$ & $\begin{array}{l}0,39 \\
0,37 \\
0,57\end{array}$ & $\begin{array}{l}0,24 \\
0,23 \\
0,14\end{array}$ & $\begin{array}{l}0,02 \\
0,01 \\
0,05\end{array}$ \\
\hline$\ldots \ldots$ & $\begin{array}{l}\text { Topsoil } \\
\text { Subsoil } \\
\text { Bottom of furrow }\end{array}$ & $\begin{array}{l}6,08 \\
4,44 \\
6,43\end{array}$ & $\begin{array}{c}3,31 \\
1,37 \\
11,35\end{array}$ & $\begin{array}{l}0,37 \\
0,68 \\
1,01\end{array}$ & $\begin{array}{l}0,19 \\
0,22 \\
0,21\end{array}$ & $\begin{array}{l}0,15 \\
0,15 \\
0,18\end{array}$ \\
\hline $\mathrm{W} 2 \ldots \ldots \ldots \ldots \ldots \ldots$ & $\begin{array}{l}\text { Topsoil } \\
\text { Subsoil } \\
\text { Bottom of furrow }\end{array}$ & $\begin{array}{l}6,65 \\
4,66 \\
6,32\end{array}$ & $\begin{array}{l}6,75 \\
1,54 \\
9,80\end{array}$ & $\begin{array}{l}0,36 \\
0,46 \\
0,81\end{array}$ & $\begin{array}{l}0,26 \\
0,18 \\
0,13\end{array}$ & $\begin{array}{l}0,23 \\
0,10 \\
0,19\end{array}$ \\
\hline
\end{tabular}

${ }^{*}$ See Table 1 for treatments.

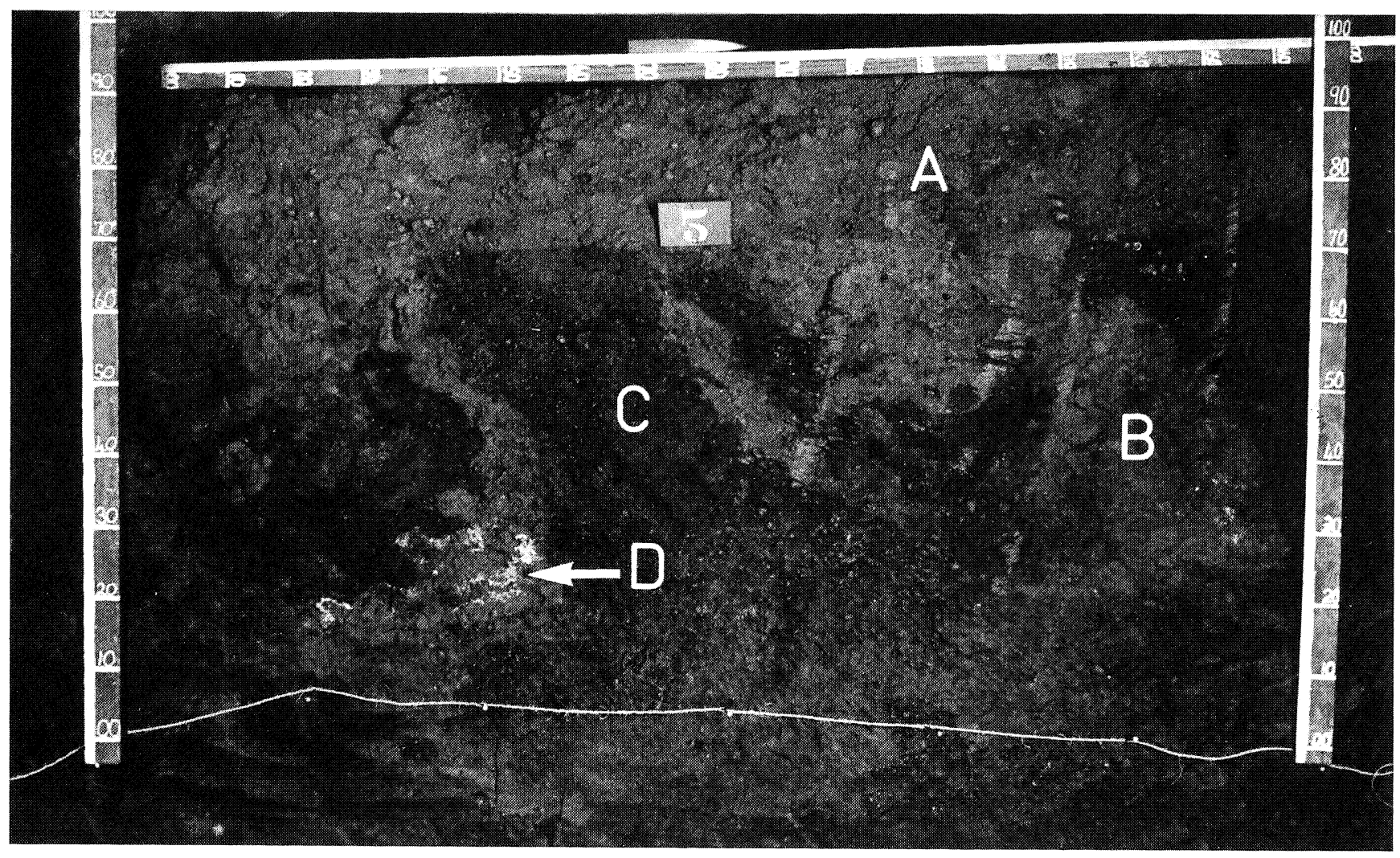

FIG. 8

Effect of ploughing a delved soil a second time: (a) double ploughed soil; (b) topsoil tongue; (c) subsoil tongue; (d) concentration of fluorescent lime. 


\section{CONCLUSIONS}

The technique of colouring lime with fluorescent pigment, and the subsequent photographing of the distribution pattern under UV light, proved to be a valuable means of investigating the effectiveness of different methods of subsoil liming.

Although the surface application of lime before deep delve ploughing was surprisingly effective, and compared well with conventional methods, or when lime was forced in with a blower, neither method resulted in the desired mixing of lime with the subsoil. An unevenly limed tongued pattern was always obtained in the case of the delve plough, whereas the winged plough gave entirely unsatisfactory results. A better distribution of lime with the latter implement would most probably be obtained if lime could be released at one or two additional levels just above the winged share, and/or by considerably increasing the volume of the air stream in which the lime is carried.

It would appear that the best distribution of lime in the subsoil could be obtained if the technique of applying lime conventionally, or on the surface, is combined with blown-in lime during deep ploughing. Deep ploughing the soil a second time would ensure still better results as far as mixing the lime with the soil is concerned. Furthermore, it is to be expected that deviating ca. $30^{\circ}$ from the original ploughing direction during the second opera- tion, would be more effective in mixing soil and lime as compared to a $90^{\circ}$ directional change.

\section{LITERATURE CITED}

EKSTEEN, L. L., 1969. The determination of the lime requirement of soils for various crops in the Winter Rainfall Region. Fert. Soc. S. Afr. J. 2, 13-14.

KOTZE, W. A. G., 1973. The influence of aluminium on plant growth. The Deciduous Fruit Grower 23, 20-22.

KOTZÉ, W. A. G., 1978. The mobility of liming materials in soils. The Deciduous Fruit Grower 28, 440-444.

KOTZÉ, W. A. G. \& DEIST, J., 1972. Aluminium in the soil. The Deciduous Fruit Grower 22, 298-300.

MACVICAR, C. N. \& SOIL SURVEY STAFF, 1977. Soil classification-a binomial system for South Africa. Dept. Agric. Tech. Serv., Pretoria. pp 152.

REEVE, N. G. \& SUMNER, M. E., 1970a. Effects of aluminium toxicity and phosphorus fixation on crop growth on Oxisols in Natal. Soil Sci. Soc. Am. Proc. 34, 263-267.

REEVE, N. G. \& SUMNER, M. E., 1970b. Lime requirements of Natal Oxisols based on exchangeable aluminium. Soil Sci. Soc. Am. Proc. 34, 595-598.

SCHULTE-KARRING, H., 1977. Strukturele tekortkominge van Suid-Afrikaanse Wingerdgronde en maatreëls om dit te verbeter. Wynboer 551, 55-62.

SHOEMAKER, H. E., McLEAN, E. O. \& PRATT, P. F., 1961. Buffer methods for determining lime requirement of soils with appreciable amounts of extractable aluminium. Soil Sci. Soc. Am. Proc. 25, 274-277. 